\title{
It's Not Easy Being Green: The Failure of Abstract Art in Gottfried Keller's Der grüne Heinrich
}

Andrea Meyertholen

\begin{abstract}
This article revisits the art and artists of Gottfried Keller's Der grüne Heinrich, a novel concluding with a conservative stance against artistic innovation, in order to explore how pre-twentieth-century literary fiction advanced the development of unconventional modes of artistic expression such as abstract art. Through comparative analysis of two fictional artworks described in the novel, I argue that Keller's nineteenth-century Bildungsroman preconditions radical twentieth-century art forms by establishing the self-awareness of the artist as necessary for the creation of unorthodox artworks. This investigation of cross-medial exchange emphasizes the cultural work performed by literature in furthering and fostering innovative visual media.
\end{abstract}

With the publication of Der grüne Heinrich (Green Henry) in 1855, Gottfried Keller presented his nineteenth-century audience with the creation of an image which, to our twenty-first-century eyes, appears to be a work of abstract art. In both the initial version as well as the 1879 revised edition of this loosely autobiographical Künstlerroman, the artwork is spawned when the eponymous protagonist finds himself at an emotional nadir due to his unsuccessful efforts at establishing a career as landscape artist. Attempting to lift his spirits, he transposes the twists and turns of his tormented soul onto canvas: 
An diese Kritzelei setzte sich nach und nach ein unendliches Gewebe von Federstrichen, welches ich jeden Tag in verlorenem Hinbrüten weiterspann, so oft ich zur Arbeit anheben wollte, bis das Unwesen wie ein ungeheures graues Spinnennetz den grö $\beta$ ten Teil der Fläche bedeckte. Betrachtete man jedoch das Wirrsal genauer, so entdeckte man den löblichsten Zusammenhang und Flei $\beta$ darin, Krümmungen, welche vielleicht tausende von Ellen ausmachten, ein Labyrinth bildete, das vom Anfangspunkte bis zum Ende zu verfolgen war. Zuweilen zeigte sich eine neue Manier, gewissermaßen eine neue Epoche der Arbeit; neue Muster und Motive, oft zart und anmutig, tauchten auf, und wenn die Summe von Aufmerksamkeit, Zweckmäßigkeit und Beharrlichkeit, welche zu der unsinnigen Mosaik erforderlich war, auf eine wirkliche Arbeit verwendet worden wäre, so hätte ich gewi $\beta$ etwas Sehenswertes liefern müssen. ${ }^{1}$

This colossal scrawl would seem to constitute an example of abstract art emerging decades before Kandinsky would unveil the first publicly-hung abstract painting in 1911. Yet neither Keller's narrative image nor Kandinsky's painted one actually introduced the Western world to the idea of abstract art. If we, for the sake of convenience, define abstract art as one not based on the premise of mimetically reproducing objects of physical reality, early literary examples of abstraction or the awareness of its possibility can be found scattered throughout the past several centuries. That authors conceptualized these unconventional images in writing well before artists produced them in paint calls 
for critical examination of the role of literature in advancing the development of innovative modes of artistic expression like abstraction.

For Kandinsky to present his revolutionary paintings entailed the assembling and aligning of an essential set of criteria, that is to say, preconditions that would facilitate an artist's creation and exhibition of an abstract artwork as physical object, as well as a public's reception and acceptance of it. Playing a role in this process, pre-twentiethcentury literature directly or indirectly explained what a visual image could not, namely the existence of these bizarre images: how they came to be, what they could convey, how the viewer could approach a work of abstraction, and what type of artist came to create it. As my investigation will demonstrate, however, Keller's protagonist is not this type of artist. In fact, the novel assumes an arguably conservative stance against aberrant manifestations of idiosyncratic expression when Heinrich's artistic journey ends with a quiet death in the first version, a life of civil servitude in the second, and his scrawl discarded in both. Nevertheless, I contend that Keller does advance the development of the art forms he appears to discourage, for the failure of Heinrich and his art reveals a crucial precondition for the future success of unorthodox artworks: the self-awareness of the artist. In exploring how writing about artistic innovation, even dissuasively, served to influence its creation, I emphasize the valuable cultural work performed by literature in fostering innovative visual media.

To date, scholarly discussions of Heinrich's scrawl have revolved around interpretations of the image itself. Otto Stelzer (1964), Karl Fehr (1972), Oskar Bätschmann (1989), and Günter Hess (1995) boldly answer claim it as an early example of abstract art. $^{2}$ Others, such as Gerhard Kaiser, draw carefully qualified correlations to 
imply that the radical artwork, though not in and of itself abstract, is indicative of impulses and images which would later be recognized as such. ${ }^{3}$ Barbara Naumann likewise locates the seeds of modern abstract art within Heinrich's handiwork, while Erich Meuthen identifies Heinrich's scrawl as a signpost pointing the path toward modernity, and reads Keller's novel as a harbinger of modern art. ${ }^{4}$ As Naumann and Meuthen suggest, our knowledge of the aesthetic forms and discourses in the decades following the book's publication predisposes our perception of Heinrich's sprawling scrawl as inherently modern and comparable to abstract art.

On the other hand, many have made the comparison only to dismiss it. In fact, Naumann and Meuthen go on to characterize this path to modernity as a dead end leading nowhere, their respective interpretations understanding the scrawl and the psychomechanical aspects of its creation as indicative of Heinrich's pathological character flaws. ${ }^{5}$ Rejecting claims for abstraction more strongly, Bruno Weber regards the passage as an ironically recounted portrayal of absolute ineptitude and creative impotence. ${ }^{6}$ Ernst Osterkamp echoes the sentiment with the contention that Heinrich's scrawling is not evidence of artistic progression, rather of human regression. ${ }^{7}$ Yet discrediting Heinrich's image with words invoking pathology and regression still indicates its potential, for it is precisely this pathological dimension which would be embraced by certain twentieth-century strains of abstract art. ${ }^{8}$ Within the nineteenthcentury context of the novel, however, these same features do not register as art, let alone as an inventive mode of aesthetic expression like abstraction. Heinrich's scrawl lands in the trash heap after friend and fellow artist Erikson puts his fist through the canvas, an action reifying classical aesthetic norms and the bourgeois social order. 
To account for its failure, we must turn from the aberrant artwork itself and cast a critical eye on the artist who folds in the face of criticism and accepts, even welcomes, the destruction of his work. Keller does level such a gaze at Heinrich, many in fact. These gazes originate from within a painting encountered earlier in the novel. A programmatic piece of representational art in the style of a Dutch genre scene, this other painting represents the converse of the scrawl. It is accordingly executed by a figure often regarded as Heinrich Lee's alter ego: the mysterious Ferdinand Lys. ${ }^{9}$ Although Keller scholarship largely overlooks this fictional painting, I bring it to the foreground in order to show how it in fact foreshadows the fate of the scrawl, and serves a crucial function for the title artist's career. ${ }^{10}$ As close textual reading demonstrates, marked parallels connect how Heinrich reacts to Lys's painting with how he then fails to react later in the novel when his scrawl is viewed and disparaged by Erikson. A comparison of the two episodes reveals that the protagonist himself ultimately dooms the drawing to failure, because he lacks the wherewithal to insist upon its legitimacy in the face of negative reception. While the scrawl fails in the novel, Lys's painting suggests to the reader that Heinrich could have acted differently, and that his abstract image could have constituted an underappreciated moment of great artistic innovation had the artist possessed the selfawareness to uphold its distinction from the orthodoxy.

Keller introduces the character of Lys upon Heinrich's arrival in Munich, where both the protagonist and his alter ego have relocated to pursue their careers as artists. Whereas Heinrich heads north from Switzerland, Lys travels southward out of the Netherlands. The former struggles to gain income and acclaim, while the latter enjoys independent wealth and notable talent. That these antithetical qualities extend to their 
artistic identities becomes evident when Heinrich visits the atelier of his new friend.

Wandering into the last chamber of Lys's studios, he finds himself before a monumental group portrait. Of its six individuals, all save one face outward; a total of five pairs of eyes converge at the spectator with expressions of unflinching scorn. Heinrich informs the reader that the composition was inspired by a Bible verse, "Wohl dem, der nicht sitzet auf der Bank der Spötter!” (426-427). ${ }^{11}$ The significance of this biblical association unfolds as the text delivers an exacting description of this imagined painting.

Under Lys's brush, the "scornful” group consists of five men in eighteenthcentury costume: a youth of barely nineteen (“der Jüngling”), a silver-haired old man (“der Greis"), a buffoon (“der Taugenichts"/ "Hanswurst”), a dignified man in uniform ("ein stattlicher Mann in Uniform"), and an abbot in silk soutane ("der Abbé"). The setting distinctly Italian, the party resides in a Roman villa with champagne sparkling in the tall Venetian glasses on the marble table before them. On the opposite side of the table, a young girl sits alone with her back to the spectator. Although both hands are occupied with the task of tuning a lute, she still drinks from a glass held to her lips by the man closest to her, the youth. The sole woman in the group is also the sole figure partaking in the libations, though she does not actually drink the wine herself. It is poured directly into her mouth by the youth, who "sah beim lässigen Hinhalten des Glases nicht auf das Mädchen, sondern fixierte den Beschauer." He is not alone, for all glances except for the girl's are directed at the person standing directly before the picture, and each pair of eyes stares at the spectator with undisguised, or poorly disguised, scorn.

At odds with the "verneinender Natur" generated by such scorn is the painting's execution, which, as Heinrich relates, is “mit dem wärmsten Leben getränkt." He further 
notes how the "Widerspruch zwischen dem freudigen Glanz und dem kritischen Gegenstand des Bildes die sonderbarste Wirkung hervorrief.” The scornful stares:

schienen mit unabwehrbarem Durchdringen jede Selbsttäuschung, Halbheit, Schwärmerei, jede verborgene Schwäche, jede unbewußte oder bewußte Heuchelei aus ihm herauszufischen. Auf ihren eigenen Stirnen, um ihre Mundwinkel ruhte zwar unverkennbare Hoffnungslosigkeit; aber trotz der Blässe, die ohne den rötlichen Greis alle überzog, steckten sie in einer unverwüstlichen Gesundheit, wie die Fische im Wasser, und der Betrachter, der seiner nicht ganz bewußt war, befand sich so übel unter diesen Blicken, daß man eher versucht war auszurufen Weh dem, der vor der Bank der Spötter steht (426-427)!

By inverting the Bible verse, Heinrich subverts the status of the spectator and the stability of his spectatorship. The position of detached onlooker should be "Wohl," or "blessed"; safely outside the picture, the audience is unable to sit with the scornful, but able to pass judgment on them. In Lys's composition spectatorial distance is cursed. By not sitting with the scornful, the spectator becomes the object of their scorn, thereby reversing the standard relationship between audience and art. No longer does the spectator actively view a purely passive object. Now the art actively confronts its audience, turning the spectator into the object of vision and assuming the privileged position of passing judgment on those who might judge it. Truly, the scornful stares of the depicted men deliver a damning verdict. 
The spectator, in turn, is acutely aware of the painting's disapproval, as the uncomfortable sensations evoked within Heinrich indicate. With every self-deception, hidden weakness, and hypocrisy forcibly extricated and brought to the surface for all to see and judge, Heinrich feels exposed and highly self-conscious of his shortcomings. He is hardly the first; Lys recounts how he occasionally would bring an unsuspecting guest or two up to this canvas to observe "die verlegenen Gesichter, die er schnitt." While the artist takes general pleasure in turning the tables on his audience, the painting's scorn is directed at one group in particular. We learn from Heinrich that "Lys nannte dies Bild seine 'hohe Kommission,' den Ausschuß der Sachverständigen, vor welchen er sich selbst zuweilen mit bangem Herzen stelle." Not merely allegorical figures, the men represent the critics who have expressly judged Lys and his art. Through this painting, however, the Dutch artist undermines the integrity of the high commissioners' judgment by at once mocking the critical audience and issuing a defiant challenge. ${ }^{12}$ As the ensuing analysis submits, Lys mocks the institution of art criticism by portraying it as a commedia-dell'arte production. In doing so, he challenges his critical audience, rejecting the critics' scorn by dislocating and objectifying them as receptacle of the artist's scorn. Closer examination of the painting's staging and deep structure reveals how the Dutchman achieves both.

The power play commences on the surface level where numerous correlations link the spectacle staged on canvas with many salient characteristics of the commedia dell'arte, the theatre genre notorious for its bawdy content and social criticism. ${ }^{13}$ To begin with, although Lys explicitly states that the work is directed at his German critics, he sets the scene in Italianate surroundings and clothes the group in costumes dating to 
the eighteenth century, a period when the commedia enjoyed renewed popularity in rococo art and porcelain sculpture. ${ }^{14}$ Most striking is his use of caricatured social types and theatrical pretense. The youth, the old man, the buffoon, the man in uniform, and the abbot comprise a cast of stock characters whose social stations are transparently identifiable through age or clothing. The male figure highlighted to the greatest extent by Lys's painting and Heinrich's narration is the most popular in the commedia, the buffoon. He sits center stage, directly across from the maiden and from the spectator, and stares “mit offenbarem Hohne, die Nase verziehend.” (427). Compounding the fool's derision are his feeble attempts to conceal it by holding a rose before his mouth, a gesture which signals a fundamental hypocrisy within the character.

This hypocrisy points to another feature intrinsic to the commedia, namely the use of masks. Although no mask as such appears in the painting, each man wears the mask of social pretense, presenting to the viewer a public façade crassly at odds with the essential nature of the being disguised underneath. To be sure, widely drawn affected gestures clearly implicate each scornful man in the painting in some form of hypocritical behavior or "masking." 15 The beautiful youth carries "die Erfahrungen eines Greises in sich," the old man exudes "allen Mutwillen eines Neunzehnjährigen.” The buffoon holds a rose in front of his mouth, "als wolle er denselben gutmütig verhehlen.” The man in uniform looks "fast schwermütig, aber doch mit mitleidigem Spotte," while the abbot of all people “eine Prise zur Nase führte und in diesem Geschäft einen Augenblick anhielt, so sehr schien ihn die Lächerlichkeit, Hohlheit oder Unlauterkeit des Beschauers zu frappieren und zu bösen Witzen aufzufordern." Yet even as the abbot and his companions conduct themselves in false and deceptive manners, they scorn the object of their gaze, and would 
seek to extract feelings of inadequacy and evidence of hypocrisy from the spectator. Lys's painting suggests that these insincere men are in no position to determine the sincerity of the viewer, even if they have been placed in such. As a result, this superficial moment of social revelry invites at a deeper level an occasion for incisive social commentary.

As indicated by the title, his commentary takes aim at the board of high commissioners, those who preside over Munich's art world. Staged as a commediadell'arte production, the art critics and the process of going before them are reduced to farce and charade, a true "comedy of artists," as it were. Only donning the masks of art critic, the group of "experts" pretends to possess aesthetic taste and act judiciously when, in reality, they lack merit and integrity. Their "expert" opinions have weight, especially for fledgling artists, but the painting challenges the veracity of their words and undermines the nature of their power. If the critics themselves are not above reproach, perhaps these men are not the best determinants for the value of art, for their judgments and damnations might be wrong. Perhaps the artist could insist on the legitimacy of his own perspective and would not have to accept his audience's criticism. Lys for one rejects the judgments of the high commissioners through the composition of his picture. It forces the critics to cast a critical eye on their own behavior, redirecting the scornful gaze of the audience at the audience, so that the judges become the judged. ${ }^{16}$

Effecting this turnabout is the faceless maiden, the axial point where spectator and painting converge, and where viewing subject becomes viewed object. She serves a paradoxical purpose, bringing the spectator into the painting's theatrical performance while at the same time ensuring utter detachment from it. ${ }^{17}$ On the one hand, as a 
backward-facing figure ("Rückenfigur") sitting closest to the picture plane, she functions as a point of identification that invites the audience to sit in her seat. ${ }^{18}$ Assuming her place at the table, however, establishes an unfairly distributed balance of power by placing the spectator in a vulnerable position. Not only is she outnumbered five to one, an estrangement further intensified by the gender divide, but her coding as performer and prostitute puts her firmly on the receiving end of things. Her figure, "üppig gewachsen" and "festlich geschmückt," betrays the likely social station of courtesan, as do the two symbols of earthly pleasure in her orbit: a lute and the wine flowing from the youth's hands into her waiting mouth. ${ }^{19}$ Providing the entertainment sexually and musically, she exists for the men's viewing pleasure, if only they would glance at her.

Their scornful stares are reserved for the spectator, who, despite identifying with the female Rückenfigur, is still detached enough from the painting to be objectified by it. As Heinrich discovers when feeling acutely on display under the piercing gazes of the men, identification is only partial. While the maiden does invite audiences into the painting, she also institutes a barrier blocking their entry. Her backward-facing body pushes them back out of the picture, and distances the spectator from the proceedings to remain an object of vision for the men. Were identification with her complete, the audience would be fully inside the picture and in her seat at the table, and thus not be objectified by the scornful stares passing over her head. Yet because the maiden paradoxically enables audience participation while effecting its alienation, her presence preserves the definable distinction between artwork and spectator, so that one may view the other. As a site of split-identification, the maiden acts as pivot point between subject and object where viewing subject in fact becomes viewed object. Therefore, when 
spectators like Heinrich are paraded out before the "Hohe Kommission," the painting obliges them to play the role of maiden in this farce. Occupying the lower and weaker end of a fundamentally inequitable balance of power, they must endure the scornful and objectifying gazes of men who, through the masks of their own hypocrisy, have little to no authority to sit in judgment.

That Lys equates this comedic production and its cast of characters with the practice of art criticism impugns the "expert" opinion of the critic, but it also implicates those artists who must bring their work before the commissioners. Assuming a role comparable to the maiden, the artist undergoes a parallel split whereby he acts as a member of the troupe who is nonetheless distanced from the performance. As a successful career requires the approval of "experts," the artist must play along in the comedic routine, performing on stage with the ensemble but also for the ensemble. Like the maiden with her lute, the artist prostitutes himself and his talents to entertain the commissioners. Hence he participates in the charade, while nonetheless standing apart from it as the object of vision, scrutiny, and scorn. For Lys, the theatre of art criticism degrades the artist compelled to play along for the sake of his career. Even he, a gifted and seasoned painter, steps in front of their critical stares with trepidation. To go before the high commissioners is to be vulnerable, to be put on public display, and to open oneself to the derision of those whose words have power, but not necessarily integrity or truth. It is to experience the same sensation that Heinrich feels when under the scornful stares in the portrait. Indeed, it is what Lys means every spectator to feel when walking under the artwork's battery of gazes. 
Yet it is when Lys presumably presents the "Hohe Kommission" before the actual board of high commissioners that something special happens. When the committee of "experts" sits in judgment of this painting, they become the spectators in its crosshairs. They view the maiden as a site of split-identification and are now made into the objects of scorn, their own scorn to be exact. The act of exhibiting the confrontational creation in this context reverses the directionality of stares, and allows Lys to project the artist's scorn onto the critics. He brazenly declares his contempt for these "experts" and the enterprise of art criticism as they perform it. This gesture of projection works to emasculate the critics under the same objectifying gazes they level at the artist. Objectified by their own scorn, judged by their own judgments, the critics are forced by the hand of the artist to face their personal shortcomings and hypocritical behavior. Throwing their stares back in their faces, Lys categorical rejects their scorn, and restores the balance of power between artist and audience. This gesture of rejection is a crucial moment of self-awareness for the artist, one which expresses belief in his work and lays claim to an artistic identity independent of audience reception. Lys asserts his authority to accept or reject the opinion of others, be it scorn or praise. As artist, he determines the parameters of his personal aesthetic consciousness, and acts as judge and defender of his own art.

The reversal of scorn illustrates a fundamental necessity for the emergence of innovating artists and unconventional art forms: a strong sense of self-awareness. Lys's defiance when confronted with an unduly critical audience signals his willingness to defend his artwork against (perceived) unjust criticism, as well as his unwillingness to acquiesce to perspectives counter to what he believes. This measure of self-awareness 
precipitates the opening of alternate perspectives which do not conform to the mainstream. Such nonconformist perspectives not only nurture novel modes of expression such as abstract art, they also endow the artist with the autonomy to define concepts such as art, success, and failure on his own terms. In commanding the judges to judge themselves, the confrontational gazes in Lys's painting suggest that any supposed shortcoming might be attributable to the audience's blindness rather than the artist's failure. Sustaining these opened alternate perspectives allows for the possibility that different sets of eyes could look at the same image but not necessarily see or respond to the same thing. That being said, it appears to fall upon the artist to open this perspective, and fight for its viability. Instead of caving to the social pressure exerted by the scornful stares, Lys demonstrates the wherewithal to assert his authority as artist to produce art as he envisions it. Moreover, in rejecting negative judgment and refusing to comply with a sense of self constructed through the eyes of others, he establishes his artistic identity as one largely contingent on internal determination as opposed to external assignment.

In stark contrast, Keller's protagonist possesses neither the willingness nor wherewithal to act as Lys does. On two separate yet interconnected occasions, Heinrich is unwilling or unable to assert himself and defend his work against the negative judgment of others. The first occurs when Heinrich walks before the "Hohe Kommission" and becomes the object of the picture's scornful yet hypocritical gazes. Lys's painting functions as a litmus test to ascertain how Heinrich might react when he, as the professional artist he wishes to become, must expose himself and his art to the critical eyes of the actual board of high commissioners. Keller does not lead the reader to presume that the young aspirant would fare well. Overwhelmed with feelings of 
insecurity, inadequacy, and incompetence, Heinrich is rendered incapable of verbal articulation, and silently makes the embarrassed faces ("verlegene Gesichter") as Lys's other guests do. The stares seem to cut into Heinrich, reaching an internal level where he is stuck dumb and unable to speak even after Lys leads him away from the judgmental committee: he "wußte nicht ein Wort zu dem Gespräche beizutragen.” Whereas Lys challenges the gazes of his critics, Heinrich's silent discomfort points to a hesitancy, even inability, to respond in a similar manner when the opportunity to do so arises.

Paralleling the portentous scene with Lys's painting, the episode elicited by Heinrich's scrawl presents the protagonist with a second occasion to respond to negative judgment, this time with respect to his own artwork. The circumstances surrounding the public viewing of the scrawl replicate Heinrich's encounter with Lys's “Hohe Kommission," only the scornful stares in the theatrically staged painting are replaced with the overblown theatricality of Erikson's derisive critique. Although the character of Erikson and the content of his monologue deserve richer treatment than can be given here, relevant to the matter at hand is the breed of artist and type of audience that he embodies for Keller. Unlike Lys, Erikson is a perfectly mediocre commercial artist (“Handelsmaler") who makes a perfectly comfortable living by painting perfectly mediocre art. A straightforward and simple creature eschewing extremes and not deviating from the road well-traveled, Erikson enjoys great financial and popular success without producing great or innovative work. He panders to the Biedermeieresque expectations of midd-leclass customers with an oeuvre consisting of variations of one theme: the "allereinfachste Landschaftsbilder im kleinsten Maßstabe, belebt mit vorsichtig hingesetzten Figürchen" (420). His reliance on established convention and 
alignment with bourgeois economic interests comprise his aesthetic taste, and give the reader reason to doubt any "expert" opinion he might issue.

Nonetheless, his scornful condemnation and destruction of Heinrich's scrawl remain unchallenged for the simple fact that Heinrich does not act to challenge it. The decisive moment for action occurs during the monologue Erikson delivers in response to his young friend's work. Halfway through his commentary, his new wife Rosalie interjects to exclaim, “"Aber, liebster Mann, wo willst du hin!”" (513). Flustered, Erikson pauses, opening his mouth and his eyes, as if momentarily uncertain of how to answer or what to say. This pause presents a prime opportunity for Heinrich's action. It does not last long, but Keller draws it out by drawing our attention to Heinrich. This is the younger artist's moment to say or do something: to disagree with Erikson and defend his scrawl, to explain the process of its creation, to assert his voice as artist. Here is a moment when Heinrich could insist upon the legitimacy of his creation, and abstract art could emerge as a real possibility for artistic expression. Yet nothing happens.

The moment is rife with a potentiality unseized by the protagonist, who silently stands "verlegen am Fenster" ("at the window, embarrassed") (513). ${ }^{20}$ The moment for potential action ends when Erikson launches into the second half of his critique, an ensuing paragraph of commentary which climaxes with the older artist's fist punched through the scrawl, and Heinrich still standing by in idle silence. Upon this true occasion of public reception and critical resistance to his work, Heinrich does not resist Erikson's resistance. He does not act out in anger, he does not act out in creative defiance like Lys and his confrontational painting, nor does he even act out to save his own creation from physical destruction. He does not act, period. Yielding to his reproving friend, the 
younger artist finally albeit silently manages to move at the episode's conclusion, but only to extend his hand in thanks ("ich reichte ihm dankbar die Hand"), grateful that Erikson has acted for him (515). The existence of the image itself ends with Erikson's action, but the existence of its potential to be abstract art ends with Heinrich's inaction, specifically his failure to act or speak during the pause in Erikson's commentary. Therein lays the problem, for Heinrich's career as artist as well as for the emergence of novel art forms such as abstraction. Since doing nothing provokes no change in established norms, Heinrich's inaction ends any potential for his scrawl to represent a legitimate mode of aesthetic expression. As a result, any aperture for an alternative perspective willing to entertain the possibility of an art that could be abstract is sealed shut.

I believe that a probable cause for the protagonist's inaction can be found in the author's language. In the original German, Keller qualifies Heinrich's passive silence with the word "verlegen," both when challenged by Erikson and when confronted with Lys's painting. Its current use designating a feeling of embarrassment, the term "verlegen" is etymologically rooted in inaction. Per Duden, the middle-high German equivalent denotes a long period of inactivity during which one incurs damage or detriment as a result of this excessively inert state (“durch langes Liegen Schaden nehmen oder träge werden"). ${ }^{21}$ While this definition certainly pertains to the protagonist's behavior in the novel, it is in the word's contemporary usage where embarrassment manifests itself as a viable explanation for Heinrich's silent inaction. Duden defines the adjective or adverb "verlegen" as an expression of uncertainty and helplessness occurring when one is in an awkward, unpleasant situation and does not know how to act or conduct oneself ("in einer peinlichen, unangenehmen Situation nicht so recht wissend, 
wie man sich verhalten soll; Unsicherheit und eine Art von Hilflosigkeit ausdrückend"). ${ }^{22}$ At once powerfully personal and socially situated, it is an emotional state involving internal sensations elicited by external conditions or conditioning. While these internal sensations can range from intense discomfort to doubt and from confusion to selfconsciousness, they typically arise from the awareness that one has committed a socially unbefitting transgression witnessed by others. The feeling of embarrassment would then presuppose an awareness of socially acceptable behavior, and involve the unwanted attention resultant of its violation.

Accordingly, Heinrich's embarrassment in the novel stems not from the act of creating the scrawl, rather from the fact that an audience sees it. In defying aesthetic norms, the knotted web on canvas represents a defiance of social norms and constitutes visual proof of Heinrich's socially unacceptable behavior. Standing “verlegen am Fenster" in response to Erikson's words, he is caught in a social transgression and does not know how to extricate himself from the spider web-hence his convenient perch by the window, a symbolic desire for a "way out." The architectural orifice prefigures the hole which Erikson rips in the drawing and even equates with an outlet. Before punching the canvas, he exclaims to Heinrich, "Frisch, halte dich oben, mache dich heraus aus dem verfluchten Garne! Da ist wenigstens ein Loch!" (515). As the two then look through the window of what was once the scrawl, Heinrich and the reader realize that the "way out" only opens when the offending creation is eradicated, and the conventional perspective is upheld. Heinrich is delivered from the unpleasant situation, and brought into conformity with social expectations. His embarrassed silence and passive response to Erikson's scorn indicates that he has tacitly accepted and internalized the judgment externally assigned by 
his audience. Like the maiden in Lys's picture drinking the wine poured down her throat, Heinrich takes the criticism, the ridicule, and the scorn leveled at him and swallows it.

That he has truly accepted it and accepted it into himself is in my estimation conveyed through the conspicuous recurrence of "verlegen." As noted above, this particular feeling, indeed this particular word, appears in conjunction with Heinrich's response to the "Hohe Kommission" as well as Erikson's critique of the scrawl. In Lys's atelier, Heinrich's narration tells of "verlegene Gesichter," the embarrassed faces made when the scornful stares in the painting appear to recognize his self-deceptions, hypocrisies, and inadequacies. What is originally imagined in the eyes of others is then acknowledged within himself, received and accepted through his silence. Shortly thereafter, the word surfaces again when Heinrich stands "verlegen am Fenster" during the pause in Erikson's scornful monologue.

Yet Keller actually uses the term a second time to describe Heinrich's response to Erikson's critical viewing of the scrawl. When the older artist first sees Heinrich's work, he stares at his young friend with a dubious or critical expression ("mit bedenklichem Gesichte”) (512). Perceiving Erikson's doubt and possibly sensing the impending critique, Heinrich becomes "verlegen und rot." This sign of outward embarrassment initiates a lopsided silent dialogue between critic and artist. It is lopsided in the sense that the critic's gaze occupies the dominant position of power: an actively viewing subject (Erikson) versus a passively viewed object (Heinrich), who registers his receipt of the stare through blushing. The physical response serves as a rejoinder continuing the wordless exchange between the two artists: Erikson conveys his dubious stance toward the scrawl, Heinrich receives and internalizes the social reproach in his embarrassment, 
and then makes his internal feelings externally apparent in turning red. Of course, this is not the first lopsided dialogue between scornful critic and embarrassed artist encountered in the novel; we recall Heinrich's embarrassment before Lys's "Hohe Kommission," a painting which deliberately contrives the unpleasant experience of the artist-critic dialogue. It is therefore not wholly surprising that Heinrich, initially "verlegen und rot," later stands "verlegen am Fenster" and does not act to defend his creation when the opportunity arises. He has already internalized the social censure and conformed to the perspective that his abstraction has no potential as art.

Emphasizing the significance of the protagonist's embarrassment, Keller juxtaposes Heinrich's reddened state with the pointed use of his epithet by Erikson in the next sentence. For our "grüner Heinrich" to turn red signals a change in his being and identity, one remaining in effect to the novel's end. Like his father's green coat, Heinrich wears his embarrassment on his body as a sign. While the coat signifies his purported profession, his redness is a sign that he has accepted and internalized the judgment of others. Suddenly Heinrich is less "green" than he previously knew himself to be, for, until his scrawl was scorned by Erikson, he understood himself as an artist, even if this identity was not fully formed. The critical response of his audience and his passive submission to it cast doubt on a once-assured identity that is never brought to fruition.

His career as artist effectively ends here, as the scrawl is the last new work that Heinrich ever creates. As suggested by his early work (fanciful cloud studies and grotesque landscapes) and confirmed by his overall lack of success, Heinrich exhibits no desire to produce conventional art that would appeal to a bourgeois market or its critics. Nor does he have the wherewithal or sense of self to reject the perspectives of others, and 
defend the work he produces. Heinrich's inaction enables Erikson's destruction of the scrawl, because it conveniently provides him a "way out" of unpleasant criticism at that moment. In the larger trajectory of the story, Heinrich's inaction saves him from the action of forming his identity as artist. In being "verlegen" and passively internalizing externally imposed parameters, Heinrich is "verlegen" in the verbal sense of the word: to displace, mislay. ${ }^{23}$ When the censorious gazes and words of his audience instill in him the feeling of being misplaced, Heinrich allows himself to be displaced as artist by not acting against his critics and for his art. At the end of the novel, he is accordingly displaced from his original career path into a life of civil servitude.

This denouement of social displacement is absent from Keller's initial 1855 publication, which tragically concludes with the hero dying quietly in poverty and solitude as a failed artist. In the second version, Keller resuscitates the artist but not his career; Heinrich still fails at art, but finds a new life in a new social role. Resolving the story in this manner reaffirms the cultural norms already in effect instead of proffering the potential for new ones. Heinrich's final integration into society as civil servant is also the integration of his individual aesthetic perspective into the mainstream conventions of the communal whole. The fact that Keller did revise the conclusion suggests a reading of the scrawl episode that cautions against new aesthetic possibilities such as abstract art, and not one heralding their potential. Even an empowered artist figure like Lys still maneuvers within the given precepts and might not be quite as defiant as his painting. Though his artistic identity is self-determined and more developed than Heinrich's, whether he would use his authority and autonomy to advocate institutional change is less definite. There is no indication that his provocative picture - still a conservative genre 
scene, I might add - experienced public exhibition or ever went before the real board of high commissioners. Implicit in Lys's defiance is the understanding that the boundaries of conventional aesthetic standards, while perhaps adjusted, will remain essentially intact.

The status of abstraction within the text, as well as the potential for its nonliterary emergence beyond its pages, rests in the hands of individuals prepared to defend its integrity. This Keller conveys through Heinrich's own lack of advocacy, for both himself and his art. In the novel, the critical audience responds to the unorthodox artwork with the resistance of an orthodox perspective working to dismantle the construction of heterogeneous perspectives. As a result, it falls upon the artist figure to either withstand the external pressure or capitulate to it. By passively yielding to his critic's position, Heinrich allows himself to be redirected back in line with social norms, a trajectory which eventually merges into prevailing aesthetic conventions and directs the protagonist toward a new profession. With Heinrich not acting to counter Erikson and save his creation from destruction, the novel concludes with a uniperspectival stance on aesthetic limits: that limits of acceptability should exist and that the scrawl violates them.

As to why it violates these limits, Heinrich's drawing conflicts with what I perceive as Keller's vision for an aesthetic sphere subject to objective standards and socioeconomic regulation. In a letter to his publisher, Keller explained: "Die Moral meines Buches ist: dass der jenige, dem es nicht gelingt, die Verhältnisse seiner Person und seiner Familie im Gleichgewicht zu erhalten, auch unbefähigt sei, im staatlichen Leben eine wirksame und ehrenvolle Stellung einzunehmen." ${ }^{24}$ In other words, social norms do not conform to the individual, rather the individual has the task of "building" himself in preparation of assuming a functional social role. The author's concern for the 
integration of the individual within the greater social organism is conveyed through a protagonist who must accommodate himself into society. Certainly, we find the classic generic callings of a Bildungsroman as we follow young Heinrich on his journey through his fictional social space, negotiating his internally driven personal proclivities with the externally enforced values of the given societal order. ${ }^{25}$ When the Heinrich of the second version accommodates himself into society as civil servant, he fails in his endeavor to become an artist. Thus, what is arguably a successful Bildungsroman is at the same time an unsuccessful Künstlerroman. Integration within the given social order precludes Heinrich's pursuit of the idiosyncratic aesthetic perspective which, in this instance, could have offered the potential for a conceptual shift toward alternative art forms such as abstraction. ${ }^{26}$

Still, Keller's conservatism is not uncritical; nor is it unsympathetic to his failed protagonist. The existence of Lys and his painting points to dissatisfaction and frustration with systemic inequities, perhaps partly due to the author's experiences involving his own unsuccessful artistic career. It also bears mentioning that the opportunity for Heinrich's potential action is unique to the second version of the novel, as is the triplicate occurrence of “verlegen.” In 1855, Erikson's critical commentary is without pause, and although Keller characterizes Heinrich as discomfited and red, he does not explicitly use "verlegen" in either scene. From these rewritings we might surmise that Keller recognized in the 1870 s a greater potential for radical change and innovation, but that even this potential required a certain type of individual ready to realize it, regardless of whether that individual should. 
In the end, Heinrich does not fail as an artist due to lack of talent or creativity. As Kaiser rightly notes, Heinrich "will als Künstler weder das Opferlamm noch der Hofnarr der bürgerlichen Gesellschaft sein. ${ }^{27}$ Keller's protagonist is unprepared or unwilling to be society's sacrificial lamb, and act in the interest of his individual aesthetic vision at the cost of his social estrangement. Though he wears his father's green coat to announce his eccentricity and differentness, he never actually leaves the social order to take up the life of bohemian artist. Never his to begin with, the coat is less a marker of his identity than it is a costume that Heinrich tries on in his own commedia-dell'arte production; it allows him to play the role of artist without actually assuming the full responsibilities or consequences of being one. Perhaps this accounts for the embarrassment Heinrich feels when before Lys's painting, a "Selbsttäuschung” or "verborgene Schwäche” momentarily made conscious under the penetrating stares of the fictional high commissioners. The especially scornful look of the buffoon standing directly opposite the spectator reminds Heinrich that he too "masks" his true self, and simply wears the costume of an artist rather than the clothes.

Yet Heinrich does not want to be society's fool either, making fanciful creations like the scrawl which provoke scorn and rebuke. That he wants to participate in the social order, not operate outside its bounds, is loudly communicated through his silent inaction at Erikson's criticism. As Kaiser also notes, “Nicht der Bürger, der Künstler steht im Grünen Heinrich unter Rechtfertigungsdruck." ${ }^{28}$ When compelled to do so, Heinrich does not act to justify or vindicate his work, such as Lys might through his intentionally provocative art or as Kandinsky later would through his written treatises. Rather, Heinrich submits to the servile role of public functionary, integrating himself into society 
by living in servitude of it. With his extraordinary life and potentially extraordinary art brought back in line with the ordinary expectations of the social order, the scrawl no longer promises a new aesthetic tendency. Instead, it is little more than the doodle Erikson sees it as.

Contrasting Heinrich's distracted doodling with “wirkliche Arbeit," Keller implies that the scrawl is not a socially useful or honorable aesthetic expression. He reduces its labor of creation to something akin to the fruitless weaving of Heinrich's old mother, who, like Penelope, sits by the window at her spinning wheel waiting in vain for the return of her unproductive son. ${ }^{29}$ Tirelessly spinning the cloth for canvases Heinrich will never paint, her wasted effort contributes nothing to the interests of society. Like Heinrich's spinning lines, the mother's spinning wheel starts as idle distraction and spirals into solipsistic behavior alienating the individual from productive social engagement. As Heinrich himself admits, the scrawl is not even a real work, let alone an early instance of abstract art.

However, the scrawl does accomplish valuable work for the emergence of abstract art in the twentieth century. Its sheer existence demonstrates that abstract images were circulating in literature well before 1900, even if artists (and authors) might not have defended or endorsed their legitimacy as art. Be that as it may, Heinrich's own lack of self-awareness allows us to establish that the self-awareness of the artist is a necessary component for the abstract painting that was to come a half century after the Der grüne Heinrich's initial publication, when artists such as Kandinksy had the wherewithal to defend their startling creations against resistant and uncomprehending audiences. ${ }^{30}$ Still resistant himself, Keller drives Heinrich to abstraction only to drive him from it, to 
express what could be, only to enforce that it should not be. He does so, perhaps, in the interest of the social organism; to convey to the reader that the potential for an abstract art would be misplaced and thus demands to be displaced, because it has no place within a well-ordered society.

My thanks to Fritz Breithaupt, Michelle Facos, Bill Rasch, and Marc Weiner for their steadfast encouragement, and to my colleagues Marc Greenberg, Lorie Vanchena, Nina Vyatkina, and Ari Linden for their continued support of my scholarly production.

${ }^{1}$ Gottfried Keller, Der grüne Heinrich, Zweite Fassung, in vol 2 of Gesammelte Werke, ed. Walter Morgenthaler (Zurich: Büchergilde Gutenberg, 1960), 511. German citations will refer to this source. An English translation can be found in Gottfried Keller, Green Henry, trans. A. M. Holt (New York: Overlook, 2003), 498-499.

${ }^{2}$ Otto Stelzer, Die Vorgeschichte der abstrakten Kunst. Denkmodelle und VorBilder (Munich: Piper, 1964); Karl Fehr, Gottfried Keller: Aufschlüsse und Deutungen (Munich: Francke, 1972); Oskar Bätschmann, Entfernung der NaturLandschaftsmalerei 1750-1920 (Cologne: DuMont, 1989); and Günther Hess, “Die Bilder des grünen Heinrich. Gottfried Kellers poetische Malerei,” in Beschreibungskunst - Kunstbeschreibung. Ekphrasis von der Antike bis zur Gegenwart, ed. Gottfried Böhm and Helmut Pfotenhauer (Munich: Fink, 1995), 373-395, as well as Hess, Panorama und Denkmal: Studien zum Bildgedächtnis des 19. Jahrhunderts (Würzburg: Königshausen \& Neumann, 2011).

${ }^{3}$ Gerhard Kaiser, "Die heilige Musa und die Musen. Himmel, Erde und der Ort der Dichtung bei Gottfried Keller," in Bilder lesen: Studien zu Literatur und bildender 
Kunst(Munich: Fink, 1981), 76-128. In Gottfried Keller: Das gedichtete Leben, Kaiser does call the scrawl a "Vorerfindung der abstrakten Kunst," explaining it as a “Spinnennetz der Mutterbeziehung." Accounting for its emergence in the novel, Kaiser views Heinrich's work as a product of the "historischen Krisenpunkt" painting experienced due to the tension between Romanticism and Classicism. See Kaiser, Gottfried Keller: Das gedichtete Leben (Frankfurt am Main: Insel, 1981), 186.

${ }^{4}$ Barbara Naumann, "Körperbild und Seelenschrift: Eine Szene in Gottfried Kellers 'Der grüne Heinrich,'” in Verkörperungen, ed. André Blum, John Krois, HansJörg Rheinberger (Berlin: Oldenbourg Akademieverlag, 2012), 217-222; Erich Meuthen, Eins und doppelt oder Vom Anderssein des Selbst: Struktur und Tradition des deutschen Künstlerromans (Tübingen: Max Niemeyer, 2001).

${ }^{5}$ See Meuthen, Eins und doppelt, 192 and Naumann, "Körperbild," 221. Additionally, traces of modernity are intuited by Regina Hebling who regards the scrawl as "verbunden mit einem romantischen L'art pour l'art-Gedanken," but ultimately dismisses it as something which for Keller "logischerweise absurd vorkommen muss." See Hebling, Gottfried Keller und seine Malerfreunde (Zurich: Neue Zürcher Zeitung, 1994), 41-42. Fritz Breithaupt likewise aligns the "Kritzelei" with a l'art pour l'art aesthetic philosophy in Der Ich-Effekt des Geldes: Zur Geschichte einer Legitimationsfigur (Frankfurt am Main: Fischer, 2008), 159-160.

${ }^{6}$ Bruno Weber, Gottfried Keller, Landschaftsmaler (Zurich: Neue Zürcher Zeitung, 1990), 64-65. 
${ }^{7}$ Ernst Osterkamp, “Erzählte Landschaften,” in Der grüne Heinrich: Gottfried Kellers Lebensbuch - neu gelesen, ed. Wolfram Groddeck (Zurich: Chronos, 2009), 141158.

${ }^{8}$ One need look no further than examples of surrealist automatism, such as André Masson's 1924 écriture automatique, now housed in the Museum of Modern Art in New York City. Other strains of surrealism along with art brut and outsider art also place value upon emotional immediacy and dissociation from rational consciousness.

${ }^{9}$ See Friedrich.A. Kittler, "Fleurs de Lys," in Fugen. Deutschfranzösisches Jahrbuch für Text-Analytik (1980), 99- 113.

${ }^{10}$ Scholarly treatment of this particular painting is sparse in both languages. Meuthen and Kaiser present the most involved analyses of the painting, each devoting several paragraphs to it (Meuthen, "Eins und doppelt, 190-191; Kaiser, Gottfried Keller 192-195). Meuthen too perceives the connection between Lys's painting and the scrawl, positing the former as a pendant to the latter. Philip Ajouri notes that the men's gazes scorn Heinrich and Lys in the dueling scene for their "Eitelkeiten und Hohlheiten," what Frauke Berndt also observes. See Ajouri, Erzählen nach Darwin: Die Krise der Teleologie im literarischen Realismus (Berlin: De Gruyter, 2007), 323; and Berndt, Anamnesis: Studien zur Topik der Erinnerung in der erzählenden Literatur (Tübingen: Niemeyer, 1999), 228. Breithaupt associates the painting with an instance of "SelbstAnklage" related to the formation of the "Ich" in "Der reine und der unreine Markt," in Markt: literarisch, ed. Thomas Wegmann (Bern: Peter Lang, 2005): 99-114, here 113. A 1919 psychoanalytical treatise by Dr. Eduard Hitschmann makes cursory reference to it, believing Heinrich's uncomfortable reaction to be a "besonders prägnante Erscheinung 
verdrängter infantiler Zeigelust der sogenannte Nacktheitstraum.” See Hitschmann, Gottfried Keller: Psychoanalyse des Dichters, seiner Gestalten und Motive (Vienna: Internationaler Psychoanalytischer Verlag, 1919), 106.

${ }^{11}$ Subsequent quotations relating to this passage are also found on these pages.

${ }^{12}$ Kaiser reads the painting as a self-conscious expose of the artist's own hypocrisies: "Dieses repräsentative Ölbild wendet sich an niemand als den Maler selbst und die wenigen, die er an seine Stelle treten läßt ... Lys kleidet sein gemaltes Selbstgericht in den Wehespruch des ersten Psalms über die Spötter ein, die am Leben nicht teilhaben, weil sie nicht nach Gottes Gebot leben" in Gottfried Keller, 192. In light of my own interpretation, I would like to emphasize one aspect of Kaiser's reading, namely its understanding of Lys as an artist who is very aware of himself as such.

${ }^{13}$ More on the commedia dell'arte can be found in Judith Chaffee and Oliver Crick, eds., The Routledge Companion to Commedia dell'Arte (New York: Routledge, 2015). While the characters in the commedia dell'arte overlap with those in the painting, the correlation is not direct.

${ }^{14}$ See for instance art by Jean-Baptiste-Joseph Pater (1695-1736) and Jean Antoine Watteau (1684-1721), or the porcelain figurines of the commedia dell'arte's stock characters manufactured in Meissen or Nymphenburg. Kaiser hints at another explanation for the Italian location, theorizing that Lys might allude to the Nazarener brotherhood of artists, in Gottfried Keller, 190.

${ }^{15}$ Kaiser observes that the men "zu Oppositionen angeordnet sind und noch einmal Oppositionen in sich tragen: ein greisenhafter Jüngling und ein jünglinghafter Greis (symbolizing “die Lebensalter”); ein Abbé mit stechendem Blick und ein 
mitleidiger Offizier (“die Stände”).” The one figure without complementary pair is the "Hanswurst," only because his opposition is the spectator: "In der Mitte, dem Betrachter genau gegenüber, Hanswurst ... der Stellvertreter schlechthin, die Person als Unperson.” Like the joker in a card game, his figure is the "Möglichkeit aller Möglichkeiten," and disguises himself to compliment the guise of any spectator. See Gottfried Keller, 193.

${ }^{16}$ Kaiser as well brings up this reversal, but he conceptualizes the effect of differently: "Der Seher begegnet sich als nichtig, und so hat das Bild auch kein Thema, sondern thematisiert seine Funktion: universales Durchschauen als universales Durchgeschaut-werden" in Gottfried Keller, 193.

${ }^{17}$ Kaiser refers to the maiden as a "blinder Fleck," the "gehaltlose Rätsel Ich zum Rätsel Frau erklärt,” and indicates both Lys's troubled relationship with women along with Heinrich's mother complex. Whereas the scrawl symbolizes Heinrich's attachment to his mother ("Der grüne Heinrich kann die Mutter nicht malen”), the woman in Lys's picture is an avatar of Rosalie who faces the rose-carrying "Narr," symbolic of Lys. That the "Narrengefecht" between Heinrich and Lys takes place in front of this painting is also mentioned by Kaiser in Gottfried Keller, 194. 
${ }^{18}$ Gustav Carus interprets the Rückenfigur as the "site of identification or mediation between painting and viewer, nature and consciousness, finite and infinite." Carus is quoted from Joseph Leo Koerner, Caspar David Friedrich and the Subject of Landscape (London: Reaktion Books, 1990), 245-246. Though the Rückenfigur is heavily treated in literature involving the Romantic paintings of C.D. Friedrich, earlier artists such as Giotto, van Eyck, and Pieter de Hooch also employed it. For literature on the Rückenfigur beyond Friedrich, see Guntram Wilks, Das Motiv der Rückenfigur und dessen Bedeutungswandlungen in der deutschen und skandinavischen Malerei zwischen 1800 und der Mitte der 1940er Jahre (Marburg: Tectum, 2011).

${ }^{19}$ While sacred in the hands of angels, the lute also signifies profane love, such as in Titian's Venus and the Lute Player (ca. 1565-70) or in Dutch genre scenes like those of Gerrit van Honthorst: Woman Tuning a Lute, Lute Player, The Concert, Feast with a Lute Player, and Concert on a Balcony.

${ }^{20}$ Keller, Green Henry, 500.

${ }^{21}$ Wörterbuch Duden online, s.v. "verlegen,"

http://www.duden.de/rechtschreibung/verlegen_befangen_schuechtern.

${ }^{22}$ Duden, "verlegen," def. 1.

${ }^{23}$ Wörterbuch Duden online, s.v. "verlegen," http://www.duden.de/rechtschreibung/verlegen_publizieren_vertagen_verlieren.

${ }^{24}$ Keller's letter to Eduard Vieweg, dated May 3, 1950 is quoted from Jens Dreisbach, Disziplin und Moderne: Zu einer kulturellen Konstellation in der deutschsprachigen Literatur von Keller bis Kafka (Berlin: Lit Verlag Dr. W. Hopf, 2009), 48. The importance of civic activity to Keller is echoed by Georg Lukács: "Erziehung zur 
öffentlichen Wirksamkeit: das ist der leitende Grundgedanke der ganzen schriftstellerischen Tätigkeit Kellers," also in Dreisbach, Diziplin und Moderne, 48.

${ }^{25}$ More on the Bildungsroman can be found in Todd Kontje, The German Bildungsroman: History of a National Genre (Columbia, SC: Camden House, 1993); Jürgen Jacobs und Markus Krause, Der deutsche Bildungsroman: Gattungsgeschichte vom 18. bis zum 20. Jahrhundert (Munich: Beck, 1989); Gerhart Mayer, Der deutsche Bildungsroman : von der Aufklärung bis zur Gegenwart (Stuttgart: Metzler, 1992); Michael Minden, The German Bildungsroman: Incest and Inheritance (Cambridge: Cambridge University Press, 1997); and Rolf Selbmann, Der deutsche Bildungsroman (Stuttgart: J.B. Metzler, 1994).

${ }^{26}$ For more on Der grüne Heinrich as Künstlerroman and an overview of the genre, see Meuthen, Eins und doppelt, specifically 174-194; and Herbert Marcuse, Der Deutsche Künstlerroman. Frühe Aufsätze (Frankfurt am Main: Suhrkamp, 1978).

${ }^{27}$ Kaiser, commentary to Der grüne Heinrich, by Gottfried Keller (Frankfurt am Main: Deutscher Klassiker Verlag, 2007), 1028.

${ }^{28}$ Kaiser, commentary, 1027.

${ }^{29}$ For more on weaving in the novel, see Dreisbach, Diziplin und Moderne, esp. 127-140; Kaiser, Gottfried Keller, 9-11; and Klaus Schuhmacher, "Gleiten, Spinnen, Treiben, Weben. Conrad Ferdinand Meyers letzte Begegnung mit Gottfried Keller, Frühjahr 1890," in Bespiegelungskunst. Begegnungen auf den Seitenwegen der Literaturgeschichte, ed. Georg Braungart, Friedmann Harzer, Hans Peter Neureuter und Gertrud M. Rösch (Tübingen: Attempto, 2004): 139-150. 
${ }^{30}$ For more on abstract art, see Richard Brettell, Modern Art 1851-1929:

Capitalism and Representation (Oxford: Oxford University Press, 1999); John Golding, Paths to the Absolute: Mondrian, Malevich, Kandinsky, Pollock, Newmann, Rothko and Still (Princeton, NJ: Princeton University Press, 2000); and Anna Moszynska, Abstract Art (London: Thames \& Hudson, 1990). 


\section{Works Cited}

Börsch-Supan, Helmut.“Berlin 1810. Bildende Kunst: Aufbruch unter dem Druck der Zeit.” Kleist-Jahrbuch. Berlin: Erich Schmidt Verlag, 1987. 52-76. Print.

Kleist, Heinrich von. "Empfindungen vor Friedrichs Seelandschaft." Sämtliche Werke und Briefe. Zweiter Band. München: Carl Hanser Verlag, 1965. 327-328. Print.

\section{Bibliography}

Begemann, Christian. "Brentano und Kleist vor Friedrichs Mönch am Meer. Aspekte eines Umbruchs in der Geschichte der Wahrnehmung." Deutsche Vierteljahrsschrift für Literaturwissenschaft und Geistesgeschichte 64 (1990): 89-145. Print.

Bexte, Peter. “Augenlider weggeschnitten. Antike Blendung: Cicero als Quelle für Kleists Diktum zu Friedrichs Mönch am Meer.” Süddeusche Zeitung 6 February 2009: 14. Print. ---."Die weggeschnittenen Augenlider des Regulus. Die verdeckten Antikenrezeption in einem Wort Heinrich von Kleists.”Kleist-Jahrbuch. Berlin: Erich Schmidt Verlag, 2008/2009. 254-266. Print.

Blankenagel, John C. “The Dominant Characteristics of German Romanticism.” PMLA 55.1 (March 1940): 1-10. Print.

Börsch-Supan, Helmut. “Bemerkungen zu Caspar David Friedrichs 'Mönch am Meer.”’ Zeitschrift des Deutschen Vereins für Kunstwissenschaft, Bd. XIX (1965): 63-76. Print.

---. "Berlin 1810. Bildende Kunst: Aufbruch unter dem Druck der Zeit.” Kleist-Jahrbuch. Berlin: Erich Schmidt Verlag, 1987. 52-76. Print. 
---.“Caspar David Friedrich's Landscapes with Self-Portraits.” The Burlington Magazine 114.834 (September 1972): 620-630. Print.

---. Caspar David Friedrich. München: Prestel-Verlag, 1990. Print.

Bridgwater, Patrick. "Friedrichian Images in Expressionist Art." Oxford German Studies 31 (2002): 103-128. Print.

Brinkmann, Bodo. “Zu Heinrich von Kleists ‘Empfindungen vor Friedrichs Seelandschaft.““ Zeitschrift für Kunstgeschichte 44.2 (1981): 181-187. Print.

Brown, H.M. “'Zwischen Erde und Himmel': Kleist and the Visual Arts, with Special Reference to Caspar David Friedrich." German Life and Letters (1978): 157-166. Print.

Burwick, Roswitha. "Verschiedene Empfindungen vor Friedrichs Seelandschaft: Arnim, Brentano, Kleist.” Zeitschrift für deutsche Philologie 107, Sonderheft (1988): 33-44. Print.

Busch, Werner. Caspar David Friedrich. Ästhetik und Religion. München: Verlag C.H. Beck, 2003. Print.

Chaoli, Michel. "Devouring Metaphor: Disgust and Taste in Kleist's Penthesilea." The German Quarterly 69.2 (Spring 1996): 125-143. Print.

Drügh, Heinz J. "Prasenzen und Umwege-Kleists medienanalytische Ekphrasis." Darstellbarkeit : zu einem ästhetisch-philosophischen Problem um 1800. Eds. Claudia Albes and Christiane Frey. Würzburg: Königshausen \& Neumann, 2003. 181-208. Print.

Goldfarb, Hilliard T. “'Naïve and Sentimental’ Landscape: Schiller, Hackert, Koch, and the Romantic Experience." The Bulletin of the Cleveland Museum of Art 69.9 (November 1982): 282-296. Print. 
Grave, Johannes. “Amor als romantischer Landschaftsmaler? Nebel und Schleier bei Goethe und Caspar David Friedrich.” Zeitschrift für Kunstgeschichte 69.3 (2006): 393-401. Print. ---. Caspar David Friedrich. New York: Prestel, 2012. Print.

---. Caspar David Friedrich. Glaubensbild und Bildkritik. Zürich: Diaphanes Verlag, 2011. Print.

Greiner, Bernhard. "Das Erhabene in der Kunst als Verrückung und als Aporie: Empfindungen von Friedrichs Seelandschaft, das Guiskard-Projekt und der Zusammenbruch von 1803/1804." Eine Art Wahnsinn: Dichtung im Horizont Kants: Studien zu Goethe und Kleist. Berlin: Erich Schmidt Verlag GmbH\& Co., 1994. 106-129. Print.

---."Die > unmögliche < Wende vom Erhabenen der Natur zum Erhabenen der Kunst: Empfindungen vor Friedrichs Seelandschaft." Kleists Dramen und Erzählungen: Experimente zum 'Fall' der Kunst. Tübingen: A. Francke Verlag, 2000. 16-36. Print.

Held, Heinz-Georg. "Paradoxie des utopischen Augenblicks: Drei Kommentare zu Caspar David Friedrichs Sehlandschaft.” Weimarer Beitrage: Zeitschrift fur Literaturwissenschaft, Asthetik und Kulturwissenschaften 39.1 (1993): 107-121. Print.

Hofmann, Werner. Caspar David Friedrich. London: Thames \& Hudson, 2000. Print.

Janz, Rolf-Peter. “Mit den Augen Kleists: Caspar David Friedrichs 'Mönch am Meer.” KleistJahrbuch. Stuttgart: Verlag J.B. Metzler, 2003. 137-149. Print.

Koerner, Joseph Leo. Caspar David Friedrich and the Subject of Landscape. London: Reaktion Books Ltd, 1990. Print.

Kleist, Heinrich von. "Empfindungen vor Friedrichs Seelandschaft.” Sämtliche Werke und Briefe. Zweiter Band. München: Carl Hanser Verlag, 1965. 327-328. Print. 
Kroeber, Karl. "The Clarity of the Mysterious and the Obscurity of the Familiar: Friedrich and Turner." The Romantic Imagination: Literature and Art in England in Germany. Eds. Frederick Burwick and Jürgen Klein. Atlanta, GA: Rodopi, 1996. 338-412. Print.

Kurz, Gerhard. "Vor einem Bild. Zu Clemens Brentanos 'Verschiedene Empfindungen vor einer Seelandschaft von Friedrich, worauf ein Kapuziner." Jahrbuch des Freien Deutschen Hochstifts. Frankfurt am Main: Gebr. Knauer, 1988. 128-140. Print.

Kuzniar, Alice A. “The Temporality of Landscape.” Studies in Romanticism 28.1 (Spring 1989): 69-93. Print.

---. “The Vanishing Canvas.” German Studies Review 11.3 (October 1988): 359-376. Print.

Lambert, Sterling. "Franz Schubert and the Sea of Eternity." The Journal of Musicology 21.2 (Spring 2004): 241-266. Print.

Miller, Philip B. “Anxiety and Abstraction: Kleist and Brentano on Caspar David Friedrich.” Art Journal 33.3 (Spring 1974): 205-210. Print.

Morgan, David. "The Enchantment of Art: Abstraction and Empathy from German Romanticism to Expressionism." Journal of the History of Ideas 57.2 (April 1996): 317-341. Print.

Morton, Marsha. “German Romanticism: The Search for 'A Quiet Place.”” Art Institute of Chicago Museum Studies 28.1 (2002): 8-23, 106-107. Print.

---. "Johann Erdmann Hummel and the Flemish Primitives: The Forging of a Biedermeier Style." Zeitschrift für Kunstgeschichte 52.1 (1989): 46-67. Print.

Müller, Gernot. Man müßte auf dem Gemälde selbst stehen: Kleist und die bildende Kunst. Tübingen: A. Francke Verlag, 1995. Print. 
Rosenblum, Robert. "The Abstract Sublime.” The Abstraction of Landscape: From Northern Renaissance to Abstract Expressionism. Exhibition. October 5, 2007- January 13, 2008. Madrid: Fundación Juan March, 2007. 161-166. Print.

Saisselin, R.G. "Art as an Imitation of Nature." The Bulletin of the Cleveland Museum of Art 52.2 (February 1965): 34-44. Print.

Seeba, Hinrich C. "The Eye of the Beholder: Kleist's Visual Poetics of Knowledge.”A Companion to the Works of Heinrich von Kleist. Ed. Bernd Fischer. Columbia, SC: Camden House, 2003. 103-122. Print.

Shahar, Galili. "Fragments and Wounded Bodies: Kafka after Kleist. The German Quarterly 80.4 (Fall 2007): 449-467. Print.

Siegel, Linda. "Synaesthesia and the Paintings of Caspar David Friedrich.” Art Journal 33.3 (Spring 1974): 196-204. Print.

Simson, Otto von. Der Blick nach Innen: Vier Beiträge zur deutschen Malerei des 19. Jahrhunderts. Berlin: Edition Hentrich, 1986. Print.

Traeger, Jörg. “...As if one’s Eyelids had been Cut Away: Imagination in Turner, Friedrich, and David." The Romantic Imagination: Literature and Art in England in Germany. Eds. Frederick Burwick and Jürgen Klein. Atlanta, GA: Rodopi, 1996. 413-435. Print.

Weber, Bruno. Gottfried Keller: Landschaftsmaler. Zürich: Verlag Neue Zürcher Zeitung, 1990.

Print.

Weber, Richard A. Color and Light in the Writings of Eduard von Keyserling. New York: P. Long, 1990. Print.

Zeeb, Ekkehard. 'Kleist, Kant und / mit Paul de Man - vor dem 'Rahmen' der Kunst. Verschiedene Empfindungen vor Friedrichs Seelandschaft." Heinrich von Kleist: 
Kriegsfall—Rechtsfall—Sündenfall. Ed. Gerhard Neumann. Freiburg im Breisgau:

Rombach Verlag, 1994. 299-336. Print.

Zimmermann, Jörg. "Bilder des Erhabenen - Zur Aktualität des Discourses über Caspar David

Friedrichs 'Mönch am Meer." Ästhetik im Widerstreit: Interventionen zum Werk von

Jean-François Lyotard. Eds. Christine Pries and Wolfgang Welsch. Weinheim: VCH,

1991. 107-127. Print.

Zimmermann, Reinhard. "Das Geheimnis des Grabes und der Zukunft. Caspar David Friedrichs

'Gedanken’ in den Bilderpaaren.” Jahrbuch der Berliner Museen 42 (2000): 187-257.

Print. 